\title{
Analisis Rasio Likuiditas Dan Solvabilitas Dalam Menilai Kinerja Keuangan Pada PT. Unilever Indonesia Tbk
}

\author{
Hendry Saladin ${ }^{1}$, Reina Damayanti ${ }^{2}$ \\ ${ }^{1}$ Akuntansi, Fakultas Ekonomi Univ. PGRI Palembang, hendrysaladin43@gmail.com \\ 2Manajemen, Fakultas Ekonomi, Univ.PGRI Palembang, reinadamayanti@univpgri-palembang.ac.id
}

\begin{abstract}
This study aims to determine the financial performance of PT Unilever Indonesia Tbk, namely by analyzing the ratio in the form of liquidity ratios, current ratio and quick ratio while solvency. Using a debt to assets ratio and a debt to equity ratio. The observed data is population taken from PT Unilever Indonesia's financial statements for 2015-2017. The sample used in this study is the statement of financial position (balance sheet) and income statement for 2015-2017 at PT. Unilever Indonesia Tbk. The research method used is a quantitative method. In this research data collection techniques are documentation and study of literature. Data analysis in the discussion of this study uses the method of comparative analysis, namely research comparing data from year to year. The results of the discussion can be seen that the level of liquidity ratio of PT Unilever Indonesia Tbk during 2015-2017 as measured by the current ratio and quick ratio is considered not good, because current debt to PT. Unilever Indonesia Tbk is bigger than current assets owned by the company. The level of solvency ratio of PT Unilever Indonesia Tbk during 2015-2017 as measured by the debt to assets ratio and debt to equity ratio is considered to be unfavorable, because more than half of the company's funding is financed by debt and most of its capital is also funded by creditors.
\end{abstract}

Keywords: financial performance, liquidity ratios and solvency ratios.

\begin{abstract}
ABSTRAK
Penelitian ini bertujuan untuk mengetahui kinerja keuangan PT Unilever Indonesia Tbk yaitu dengan menganalisis rasio berupa rasio likuiditas indikatornya current ratio dan quick ratio sedangkan solvabilitas. Menggunakan debt to assets ratio dan debt to equity ratio. Data yang diamati merupakan populasi yang diambil dari laporan keuangan PT Unilever Indonesia tahun 2015-2017. Sampel yang digunakan dalam penelitian ini yaitu laporan posisi keuangan (neraca) dan laporan laba rugi tahun 2015-2017 pada PT. Unilever Indonesia Tbk. Metode penelitian yang digunakan adalah metode kuantitatif. Dalam penelitian ini teknik pengumpulan data yaitu dokumentasi dan studi pustaka. Analisis data dalam pembahasan penelitian ini menggunakan metode analisis komporatif yaitu penelitian yang membandingkan data dari tahun ketahun. Hasil dari pembahasan dapat diketahui bahwa tingkat rasio likuiditas PT. Unilever Indonesia Tbk selama tahun 2015-2017 yang diukur dengan current ratio dan quick ratio dinilai kurang baik, karena hutang lancar pada PT. Unilever Indonesia Tbk lebih besar dibandingkan dengan aset lancar yang dimiliki perusahaan. Tingkat rasio solvabilitas PT Unilever Indonesia Tbk selama tahun 2015-2017 yang diukur dengan debt to assets ratio dan debt to equity ratio dinilai kurang baik, karena lebih dari separuh pendanaan perusahaan dibiayai oleh utang dan sebagian besar modalnya juga didanai oleh kreditur.
\end{abstract}

Kata kunci : kinerja keuangan, rasio likuiditas dan rasio solvabilitas.

\section{A. Pendahuluan}

Berdasarkan fenomena yang dilihat dari tingkat likuiditas menunjukkan sejauh mana kemampuan perusahaan dalam memenuhi kewajiban jangka pendeknya dengan jaminan harta lancarnya yang dimilikinya.Rasio likuiditas berhubungan dengan nilai aktiva lancar, kewajiban lancar, kas dan pendapatan usaha menurut Kasmir (2015:128). Alat ukur mengunakan rasio lancar atau (current ratio) 
merupakan rasio untuk mengukur kemampuan perusahaan dalam membayar kewajiban jangka pendek atau utang yang segera jatuh tempo pada saat ditagih secara keseluruhan. Rasio cepat (quick ratio) atau rasio lancar acid test ratio merupakan rasio yang menunjukkan kemampuan perusahaan dalam mmenuhi atau membayar kewajiban atau utang lancar (utang jangka pendek) dengan aktiva lancar tanpa memperhitungkan nilai sediaan (inventory) menurut Kasmir (2015:136).

Tingkat solvabilitas menunjukkan sejauh mana kemampuan perusahaan dapat memenuhi semua kewajiban dengan jaminan harta yang dimilikinya. Rasio solvabilitas berhubungan dengan total aktiva, total kewajiban, utang jangka pendek maupun utang jangka panjang dan ekuitas menurut Kasmir (2015:151). Alat ukur menggunakan debt rasio adalah rasio utang yang digunakan untuk mengukur perbandingan antara total utang dengan total aktivaAnalisis rasio ini merupakan salah satu cara untuk mengukur kinerja dari sebuah perusahamenurut kasmir (2010:156).debt to equity ratio adalah rasio yang digunakan untuk menilai utang dengan ekuitas menurut kasmir (2015:157). Secarateori, apabila tingkat rasio keuangan tertentu mengalami kenaikan maka dapat diambil kesimpulan bahwa kinerja perusahaan tersebut bagus dapat disimpulkan bahwa pentingnya analisis laporan keuangan sebagai alat bantu serta sumber informasi dalam menilai kondisi keuangan.

Bursa efek atau bursa saham adalah sebuah pasar yang berhubungan dengan pembelian dan penjualan efek perusahaan yang sedah terdaftar dibursa itu. Bursa efek tersebut, bersama-sama dengan pasar uang merupakan sumber utama permodalan eksternal bagi perusahaan dan pemerintah, adapun sektor-sektor tersebut diantaranya yaitu sektor industri manufaktur antara lain; sektor industri dasar dan kimia seperti logam dan sejenisnya, sektor industri barang konsumsi seperti makanan dana minuman;

PT. Unilever Indonesia Tbk perusahan publik (emiten) yang terdaftar di Bursa Efek Indonesia sebagai perusahan manufaktur dalam sektor industri barang konsumsi (consumer good industry) sub sektor makanan, sub sektor minuman, sub sektor kosmetik, dan sub sektor keperluan rumah tangga. PT.Unilever Indonesia Tbk (perseroan) bergerak dalam bidang jasa, usaha perusahaan adalah produksi, pemasaran dan distribusi barang-barang konsumsi.

\section{B. Kajian Teori}

1) Laporan Keuangan

a) Pengertian Laporan Keuangan

Menurut IAI (2018:1.3) laporan keuangan adalah suatu penyajian terstruktur dari posisi keuangan dan kinerja keuangan suatu entitas. Tujuan laporan keuangan adalah untuk memberikan informasi mengenai posisi keuangan, kinerja keuangan, dan arus kas entitas yang bermanfaat bagi sebagian besar pengguna laporan keuangan dalam pembuatan keputusan ekonomik.Laporan keuangan juga menunjukka hasil pertanggung jawaban manajemen atas penggunaan sumber data yang dipercayakan kepada mereka.

Menurut Hery ( 2015:3) laporan keuangan ( financial statements) merupakan produk akhir dari serangkaian proses pencatatan dan pengikhtisaran bisnis.

\section{b) Tujuan Laporan Keuangan}

Menurut kasmir (2015:11) berikut ini beberapa tujuan pembuatan atau penyusunan laporan keuangan yaitu : 
$>$ Memberikan informasi tentang jenis dan jumlah aktiva (harta) yang dimiliki perusahaan pada saat ini;

$>$ Memberikan informasi tentang jenis dan jumlah kewajiban dan modal yang dimiliki pada saat ini;

$>$ Memberikan informasi tentang jenis dan jumlah pendapatan yang diperoleh pada suatu periode tertentu;

$>$ Memberikan informasi tentang perubahan-perubahan yang terjadi terhadap aktiva , pasiva,dan modal perusahaan;

$>$ Memberikan informasi tentang kinerja manajemen perusahaan dalam suatu periode;

$>$ Memberikan informasi tentang catatan-catatan atas laporan keuangan

$>$ Informasi keuangan lainnya;

\section{c) Kegunaan Laporan Keuangan}

Menurut fahmi (2011:4) kegunaan laporan keuangan untuk mengukur hasil usaha dan perkembangan perusahaan dari waktu ke waktu dan untuk mengetahui sudah sejauh mana perusahaan mencapai tujuannya. Laporan keuangan merupakan proses akuntansi yang dapat digunakan sebagai alat untuk berkomunikasi antara data keuangan atau aktivitas suatu perusahaan dengan pihak-pihak yang berkepentingan dengan data atau aktivitas perusahaan tersebut.

\section{d) Prosedur Teknik Analisis Laporan Keuangan}

Menurut Hery (2015:134) secara garis besar ada dua metode analisis laporan keuangan yang digunakan dalam praktik yaitu :

1) Analisis Vertikal (statis) merupakan analisis yang dilakukan hanya terhadap satu periode laporaqn keuangan saja. Analisis ini dilakukan antara pos-pos yang ada dalam laporan keuangan dari suatu perioode . jadi, informasi yang diperoleh hanyalah menggambarkan hubungan kunci antar pos-pos laporan keuangan atau kondisi untuk satu periode saja sehingga tidak dapat mengetahui perkembangan kondisi perusahaan dari periode yang satu ke periode lainnya. Analisis vertikal juga dapt berupa analisis perbandingan terhadap laporan keuangan perusahan lain pada satu periode waktu tertentu, dimana perbandingan dilakukan terhadap informasi serupa dari perusahaan lain yang berada dalam satu industri yang sama atau dikaitkan dengan data industri (sebagai patokan) pada periode waktu yang sama.

2) Analisis horisontal (dinamis) merupakan analisis yang dilakukan dengan membandingkan laporan keuangan dari beberapa periode. Perbandingan dilakukan dengan informasi serupa dari perusahaan yang sama (perusahaan itu sendiri) tetapi untuk periode waktu yang berbeda.

\section{2) Kinerja Keuangan}

a) Pengertian Kinerja Keuangan

Menurut fahmi (2011:239), kinerja keuangan adalah suatu analisis yang dilakukan untuk melihat sejauh mana suatu perusahaan telah melaksanakan dengan menggunakan aturan-aturan pelaksanaan keuangan secara baik dan bener.

Menurut Jumingan (2014:239) kinerja keuangan adalah gambaran kondisi keuangan pada suatu periode tertetu baik menyangkut aspek penghimpunan dana maupun penyaluran dana yang biasanya diukur dengan indikator kecukupan modal, likuiditas, dan profitabilitas. 
Menurut Munawir (2010:30) kinerja keuangan perusahaan merupakan satu diantara dasar penilaian mengenai kondisi keuangan perusahaan yang dilakukan berdasarkan analisis terhadap rasio keuangan perusahaan.

b) Bentuk -bentuk Rasio Keuangan

Untuk mengukur kinerja keuangan perusahaan dengan menggunakan rasiorasio keuangan, dapat dialkukan dengan beberapa rasio keuangan.Setiap rasio keuangan memiliki tujuan, kegunaan, dan arti tertentu.kemudian, setiap hasil dari rasio yang diukur diinterpretasikan sehingga menjadi bearti bagi pengambilan keputusan.

\section{1) Rasio Likuiditas}

\section{a. Pengertian Rasio Likuiditas}

Menurut Harahap (2010:301) rasio likuiditas megambarkan kemampuan perusahaan untuk menyelesaikan kewajiban jangka pendeknya. Dengan kata lain, rasio likuiditas adalah rasio yang dapat digunakan untuk mengukur sampai seberapa jauh tingkat kemampuan perusahaan kekampuan perusahaan dalam melunasi kewajiban jangka pendeknya yang akan segera jatuh tempo.

Menurut kasmir (2015:110) rasio likuiditas merupakan rasio yang menggambarkan kemampuan dalam mmenuhi kewajiban jangka pendek ( fred weston).

Menurut Fahmi (2011:121) rasio likuiditas (liquidity ratio) adalah kekampuan suatu perusahaan mmenuhi kewajiban jangka pendeknya secara tepat waktu.

\section{b. Tujuan dan Manfaat Rasio Likuiditas}

Menurut Hery berikut ini adalah tujuan dan manfaat rasio likuiditas secara keseluruhan.

1. Untuk mengukur kemampuan perusahaan dalam membayarkewajiban atau utang yang akan segera jatuh tempo.

2. Untuk mengukur kemampuan perusahaan dalam membayar keajiban jangka pendek dengan menggunakan total aset lancar.

3. Untuk mengukur kemampuan perusahaan dalam membayar kewajiban jangka pendek dengan menggunakan aset lancar (tanpa memperhitungkan, persediaan barang dagang dan asset lancar lainya.

4. Untuk mengukur tingkat ketersediaan uang kas perusahaan dalam membayar membayar utang jang ka pendek.

5. Sebagai alat perencanaan keuangan dimasa mendatang terutama yang berkaitan degan perencannan kas dan utang jangka panjang.

Untuk melihat kondisi da posisi likuiditas perusaan dari waktu ke waktu dengan membandingkan selama bebarapa period.

\section{c. Jenis-jenis Rasio Likuiditas}

1. Rasio Lancar (Current Ratio)

Menurut Kasmir (2015:134) rasio lancar atau (current ratio) merupakan rasio untuk mengukur kemampuan perusahaan dalam membayar kewajiban jangka pendek atau utang yang segera jatuh tempo pada saat ditagih secara keseluruhan. Rumus untuk mencari rasio lancar atau current rasio dapat digunakan sebagai berikut : 
Current Ratio $=\frac{\text { Aktiva Lancar (Current Assets) }}{\text { Utang Lancar (Current Liabilities) }}$

Standar industri : 2 kali

\section{Rasio Cepat (Quick Ratio)}

Menurut Kasmir (2015:136) rasio cepat (quick ratio) atau rasio lancar acid test ratio merupakan rasio yang menunjukkan kemampuan perusahaan dalam mmenuhi atau membayar kewajiban atau utang lancar (utang jangka pendek) dengan aktiva lancar tanpa memperhitungkan nilai sediaan (inventory).

\begin{tabular}{cc} 
Quick Ratio (Acid Test Ratio) & Current Assets - Inventory \\
\cline { 2 - 2 } & Current liabilities
\end{tabular}

\section{Standar indusrti 1,5 kali}

3. Rasio Kas (Cash Ratio)

Menurut Kasmir (2015:138) rasio kas adalah alat yang digunakan untuk mengukur seberapa besar uang kas yang tersedia untuk membayarutang. Ketersediaan uang kas dapat ditunjukkan dari tersediaanya dana kas atau yang setara kas seperti rekening giro atau tabungan dibank (yang dapat ditarik setiap saat).

Rumus untukmencari rasio kas sebagai berikut :

$$
\text { Cash ratio }=\frac{\text { Kas }+ \text { bank }}{\text { Curernt liabilities }}
$$

Standar industri : $50 \%$

4. Rasio Perputaran Kas

Menurut Kasmir (2015:140) rasio perputaran kas adalah digunakan untuk mengukur tingkat ketersediaan kas untuk membayar tagihan (utang) dan biaya-biaya yang berkaitan dengan penjualan.

Rumus untuk mencari rasio perputaran kas sebagai berikut :

Rasio perputaran kas
$=$

Standar industri : $10 \%$

\section{Inverory to Net Working Capital}

Menurut Kasmir (2015:141) inventory to net working capital merupakan rasio yang digunakan untuk mengukur atau membandingkan antara jumlah sediaan yang ada dengan modal kerja perusahaan.Modal kerja terdiri dari pengurangan aktiva lancar dengan utang lancar.

\begin{tabular}{cc|} 
Inventory to NWC & Inventory \\
\cline { 2 - 2 } &
\end{tabular}

Standar industri : $12 \%$ 


\section{2) Rasio Solvabilitas}

\section{a. Pengertian Rasio Solvabilitas}

Menurut Kasmir (2015:151) rasio solvabilitas atau leverage ratio merupakan rasio yang digunakan untuk mengukur rasio yang digunakan untuk mengukur sejauh mana aktiva perusahaan dibiayai dengan utang. Artinya berapa besar beban utang yang ditanggung perusahaan dibandingkan dengan aktivanya.dalam arti luasnya rasio solvabilitas digunakan untuk mengukur kemampuan perusahaan untuk membayar seluruh kewajibannya, baik jangka pendek maupun jangka panjang apabila perusahaan dibubarkan (dilikuidasi).

\section{b. Tujuan dan Manfaat Rasio Solvabilitas}

Menurut Kasmir (2015:153) berikut adalah beberapa tujuan perusahaan dengan menggunakan rasio solvabilitas yakni :

1. Untuk mengetahui posisi perusahaan terhadap kewajiban kepada pihak lainnya (kreditor).

2. Untuk menilai kemampuan perusahaan dalam memenuhi kewajiban yang bersifat tetap (seperti angsuran pinjaman termasuk bunga).

3. Untuk menilai keseimbangan antara nilai aktiva khususnya aktiva tetap dengan modal.

4. Untuk menilai seberapa besar aktiva perusahaan dibiayai oleh utang.

5. Untuk menilai seberapa besar pengaruh utang perusahaanterhadap pengelolaan aktiva.

6. Untuk menilai atau mengukur berapa bagian dari setiap rupiah modal sendiri yang dijadikan jaminan utang jangka panjang.

7. Untuk menilai berapa dana pinjaman yang segera akan ditagih, terdapat sekian kalinya modal sendiri yang dimiliki, dan

8. Tujuan lainnya.

Sementara itu manfaat rasio solvabilitas atau leverage ratio adalah

a. Untuk menganilisis kemampuan posisi perusahaan terhadap kewajiban kepada pihak lainya.

b. Untuk menganilisi kemampuan perusahaan memenuhi kewajiban yang bersifat tetap (seperti angsuran pinjaman termasuk bunga).

c. Untuk menganalisis keseimbangan antara nilai aktiva khususnya aktiva tetap dan modal.

d. Untuk menganalisis seberapa besar utang perusahaan dibiayai oleh utang.

e. Untuk menganalisis seberapa besar utang perusahaan berpengaruh terhadap pengelolaan aktiva.

f. Untuk menganalisis atau mengukur berapa bagian dari setiap rupiah modal sendiri yang dijadikan jaminan utang jangka panjang.

g. Untuk menganalisis berapa dana pinjaman yang segera akan ditagih ada terdapat setiap kalinya modal sendiri.

\section{c. Jenis-jenis Rasio Solvabilitas}

1. Debt to Assets Ratio (Debt Ratio)

Menurut kasmir (2015:156) Debt rasio adalah rasio utang yang digunakan untuk mengukur perbandingan antara total utang dengan total aktiva. Dengan kata lai, seberapa besar aktiva perusahaan dibiayai oleh utang atau 
seberapa besar utang perusahaan berpengaruh terhadap pengelolaan aktiva.

Debt to assets ratio $(\mathrm{DAR})=\frac{\text { Total debt }}{\text { Total assets }}$

Standar industri : 35\%

\section{Debt to Equity Ratio}

Menurut kasmir (2015:157) debt to equity ratio adalah rasio yang digunakan untuk menilai utang dengan ekuitas. Rasio ini dicari dengan membandingkan antara seluruh utang, termasuk utang lancar dengan seluruh ekuitas.

Debt to equity ratio (DER) Total Utang (Debt)

$=\quad$ Ekuitas (Equity)

Standar industri : $90 \%$

3. Long Tern Debt to Equity Ratio (LTDtER)

Menurut Kasmir (2015:159) LTDtER) merupakan rasio antara utang jangka panjang dengan modal sendiri.

$$
\text { LTDtER }=\frac{\text { Long tern debt }}{\text { Equity }}
$$

Standar industri : 10 kali

4. Times Interest Earned

Rasio ini juga diartikan oleh JamesVan Horne juga sebagai kemampuan perusahaan untuk membayar biaya bunga sama sperti coverage ratio.

\begin{tabular}{c} 
Times Interest Earned \\
\cline { 2 - 2 }
\end{tabular}

Standar industri : 10 kali

5. Fixed Charge Coverage (FCC).

Menurut Kasmir (2015:162) fixed cgarge coverage adalah rasio ini dilakukan apabila perusahaan memperoleh utang jangka panjang atau menyewa aktiva berdasarkan kontrak sewa (lease contract).

$$
\begin{array}{cc}
\text { Fixed charge coverage } & \text { EBT + biaya bunga + kewajiban } \\
= & \text { sewa/lease } \\
\cline { 2 - 2 } & \text { Biaya bunga + kewajiban sewa /lease }
\end{array}
$$

\section{Standar industri :10 kali}

\section{Metode penelitian}

Menurut Sugiyono (2014:2) metode penelitian adalah sebagai cara ilmiah untuk mendapatkan data dengan tujuan dan kegunaan tertentu. Metode penelitian yang digunakan dalam penelitian ini adalah metode penelitian kuantitatif.

Menurut Sugiyono (2014:13 ), metode penelitian kuantitatif dapat diartikan sebagai metode penelitian yang berlandaskan pada filsafat positivisme, digunakan untuk meneliti pada populasi atau sampel tertentu, teknik pengambilan pada populasi 
atau sampel pada umumnya dilakukan secara random, pengumpulan data menggunakan instrumen penelitian, analisis data bersifat kuantitatif / statistik dengan tujuan untuk menguji hipotesis yang telah ditetapkan.

\section{Populasi dan Sampel}

1) Populasi Penelitian

Menurut Sedarmayanti (2011:121) populasi adalah himpunan keseluruhan karakteristik dari objek yang diteliti atau keseluruhan dari unit analisis/hasil pengurangan yang dibatasi oleh kriteria tertentu. Melakukan penelitiaan diperusahaan PT.UniliverTbk Populasi yang digunakan dalam penelitian ini adalah laporan keuangan PT.Unilever Indonesia Tbk.

\section{2) Sampel}

Menurut Sedarmayanti (2011:124) sampel adalah kelompok kecil yang diamati dan merupakan bagian dari populasi sehingga sifat dan karakteristik populasi juga dimiliki oleh sampel. Atau Sampel adalah sekumpulan / sebagian dari unit populasi yang diperoleh melalui proses sampling tertentu.Sampling yang digunakan adalah sampling jenuh.Menurut Sugiyono (2014:122) sampling jenuh adalah teknik penentuan sampel bila semua anggota populasi digunakan sebagai sampel.Hal ini sering dilakuakan bila jumlah populasi relatif kecil, kurang dari 30 orang, atau penelitian yang ingin membuat generalisasi dengan kesalahan yang sangat kecil. Istilah lain sampel jenuh adalah sensus, diaman semua anggota populasi dijadikan sampel.

Sampel dalam penelitian ini adalah laporan keuangan yang berupa data laporan posisi keuangan (neraca) dan laporan laba rugi pada PT. Unilever Indonesia Tbk periode 2015-2017 yang merupakan bagian dari populasi.

\section{E. Jenis dan Sumber Data}

Menurut Sugiyono (2014:402) bila dilihat dari sumber datanya, maka pengumpulan data dapat mengunakan

1) Data primer

Data primer adalah sumber data yang dikumpulkan melalui penelitian lapangan yang merupakan suatu teknik pengumpulan dan informasi secara lansung dari objek yang diteliti.

2) Data sekunder

Data sekunder adalah sumber yang tidak langsung memberikan datakepada pengumpul data, misalnya lewat orang lain atau lewat dokumen.Datasekunder umumnya berupa bukti laporan keuangan suatu perusahaan yang tersusun dalam arsip yang dipublikasikan

Jenis dan sumber data yag digunakan dalam penelitian ini berupa data sekunder yaitu sumber data penelitian yang diperoleh peneliti secara tidak langsung melalu media perantara. Data sekunder dalam penelitian ini berupa data laporan keuangan PT. Unilever Indonesia,Tbk periode 2015-2017 yang bersumber dari pojok bursa efek Indonesia universitas Muhammadiyah kota palembang.

\section{F. Teknik Pengumpulan data}

Menurut Sugiyono (2014:402) teknik pengumpulan data merupakan langkah yang paling utama dalam penelitian, karena tujuan utama dari penelitian adalah 
mendapatkan data. Tanpa mengetahui teknik mengumpulan data, maka peneliti tidak akan mendapatkan data yang memenuhi standar data yang ditetapkan.Dalam penelitian ini penulis menggunakan teknik :

a. Dokumentasi

Dokumentasi adalah catatan peristiwa yang sudah berlaku. Dokumentasi ini bisa berbentuk tulisan, gambar atau karya-karya monumental dari seseorang data yang digunakan dalam penelitian ini berupa sejarah, struktur organisasi, laporan keuangan yang meliputi laporan posisi keuangan dan laporan laba rugi yang komprehensif periode 2015-2017 PT. Unilever Indonesia,Tbk yang terdaftar di bursa efek Indonesia (BEI).

b. Studi Pustaka

Studi pustaka teknik pengumpulan data mengunakan buku-buku dan linear yang dimaksudkan untuk memperoleh landasan teori yan memadai yang mendukung pembahasan yang dilakukan.

\section{G. Teknik Analisis Data}

Menurut sugiyono (2014:54) Penelitian komparatif adalah suatu penelitian yang bersifat membandingkan. Disini variabelnya masih sama dengan variabel mandiri tetapi untuk sampel yang lebih dari satu, atau dalam waktu yang berbeda, atau membandingkan data dari tahun ketahun.

Dalam penelitian ini teknik analisis data yang digunakan ialah teknik analisis komparatif.

\section{H. Hasil Penelitian dan Pembahasan \\ 1) Rasio Likuiditas \\ a. Current Ratio}

TABEL 2

\begin{tabular}{|c|c|c|}
\hline Tahun & Current ratio & $\begin{array}{l}\text { Standar } \\
\text { industri }\end{array}$ \\
\hline 2015 & 0.65 kali & \multirow{3}{*}{2 kali } \\
\hline 2016 & 0.60 kali & \\
\hline 2017 & 0.63 kali & \\
\hline
\end{tabular}

Dari hasil penelitian dapat dilihat jika rata-rata standar industri current ratio adalah sebesar 2 kali. aktiva lancar pada tahun 2015 sebesar Rp.6.623.114, pada tahun 2016 aktiva lancar mengalami penurunan menjadi sebesar Rp. 6.588.109, dan pada tahun 2017 aktiva lancar mengalami kenaikan menjadi sebesar Rp.7.941.635.

hutang lancar pada tahun 2015 sebesar Rp.10.127.542, pada tahun 2016 hutang lancar mengalami kenaikan menjadi sebesar Rp.10.878.074, dan pada tahun 2017 hutang lancar mengalami kenaikan menjadi sebesar Rp.12.532.304.makadapat dilihat hasil dari perhitungan aktiva lancar dibagi dengan hutang lancar dari tabel diatas kesimpulannya :

Menurut peneliti hasil perhitungan current ratiodiatas pada tahun 2015-2017 masih berada dibawah rata-rata standar industri. hal ini menyebabkanperusahaan dalam keadaan tidak likuid dan perusahaan juga berada dalam kondisi yang kurang baik, karena aktiva lancar tidak bisa menjamin hutang lancar atau kewajibankewajiban perusahaan yang segera jatuh tempo. 
menurut Kasmir (2018:128)pada tahun 2015-2017 semua hasil perhitungan current ratio pada tahun 2015-2017 masih berada dibawah rata-rata standar industri.Dan apabila rasio yang didapat lebih besar dari standar industri dapat dikatakan memuaskan dan dikatakan perusahaan sedang baik. dan sebaliknya apabila rasio lebih kecil dari standar industri maka sangat kurang memuaskandan dikatakan bahwa perusahaan kurang modal untuk membayar utang. walaupun mengalami naik turun hasil perhitungan rasionya tidak memperngaruhi keadaan karena baik tidak yang suatu perusahaan tergantung standar industri yang ditetapkan.

TABEL 3

Hasil Perhitungan quick ratio

\begin{tabular}{|c|c|c|}
\hline Tahun & Quick Ratio & $\begin{array}{c}\text { Standar } \\
\text { industri }\end{array}$ \\
\hline 2015 & 0.42 kali & \multirow{2}{*}{$\mathbf{1 , 5}$ kali } \\
\hline 2016 & 0.39 kali & \\
\hline 2017 & 0.44 kali & \\
\hline \multicolumn{2}{|c|}{ Sumber : data diolah oleh penulis } \\
\hline
\end{tabular}

Dari hasil penelitian dapat dilihat jika rata-rata standar industri quick ratio adalah sebesar 1,5 kali. Aktiva lancar pada tahun 2015 sebesar Rp.6.623.114, pada tahun 2016 aktiva lancar mengalami penurunan menjadi sebesar Rp. 6.588.109, dan pada tahun 2017 aktiva lancar mengalami kenaikan menjadi sebesar Rp.7.941.635.

Persediaan pada tahun 2015 sebesar Rp. 2.297.502, pada tahun 2016 persediaan mengalami kenaikan menjadi sebesar Rp. 2.318.130, dan pada tahun 2017 persediaan mengalami kenaikan menjadi sebesar Rp.2.393.540

hutang lancar pada tahun 2015 sebesar Rp.10.127.542, pada tahun 2016 hutang lancar mengalami kenaikan menjadi sebesar Rp.10.878.074, dan pada tahun 2017 hutang lancar mengalami kenaikan menjadi sebesar Rp.12.532.304. makadapat dilihat hasil dari perhitungan current assets dikurang persedian dan dibagi hutang lancar hasilnya dapat dilihat dari tabel diatas kesimpulannya adalah :

Menurut peneliti hasil perhitungan quick ratio pada tahun 2015-2017 masih berada dibawah rata-rata standar industri. hal ini menyebabkan perusahaan berada dalam kondisi yang kurang baik, disebabkan karena hutang lancar lebih besar dibandingkan dengan aset lancar yang dimiliki perusahaan dan juga karena rasio ini mengukur uji solvensi jangka pendek yang lebih detail karena tidak memasukan persediaan jika sudah tidak likuid jelas perusahaan akan mengalami kerugian.

menurut Kasmir (2018:134)apabila rasio yang didapat lebih besar dari standar industri dapat dikatakan bahwa perusahaan lebih baik dan tidak harus menjual sediaan bila hendak melunasi hutang tetapi dapat menjual surat berharga atau penagihan piutang dan sebaliknya apabila rasio lebih kecil dari standar industri maka sangat kurang memuaskan dan perusahaan lebih buruk bagi perusahaan menyebakan perusahaan harus menjual sediaan untuk membayar utangnya, padahal menjual sediaan untuk harga yang normal relatif sulit, kecuali perusahaan menjual dibawah harga pasar, yang tentunya bagi perusahaan menambah kerugian walaupun mengalami naik turun hasil perhitungan rasionya tidak memperngaruhi keadaan karena baik tidak yang suatu perusahaan tergantung standar industri yang ditetapkan. 


\section{2) Rasio Solvabilitas}

a. Debt to Assets Ratio (DAR)

Debt to Assets rasio(DAR) adalah rasio utang yang digunakan untuk mengukur perbandingan antara total utang dengan total aktiva.

TABEL4

Perhitungan Debt to Assets Ratio

\begin{tabular}{|c|c|c|}
\hline Tahun & $\begin{array}{c}\text { Debt to Assets } \\
\text { ratio }\end{array}$ & $\begin{array}{c}\text { Standar } \\
\text { industri }\end{array}$ \\
\hline 2015 & $69 \%$ & \multirow{2}{*}{$35 \%$} \\
\hline 2016 & $71 \%$ & \\
\hline 2017 & $72 \%$ & \\
\hline \multicolumn{2}{|l|}{ Sumber : data diolah oleh penulis } \\
\hline
\end{tabular}

Dari hasil penelitian dapat dilihat jika rata-rata standar industri debt to assets ratio adalah sebesar 35\%. Total hutang pada tahun 2015 sebesar Rp.10.902.585, pada tahun 2016 total hutang mengalami kenaikan menjadi sebesar Rp. 12.041.437 pada tahun 2017 total hutang juga mengamali kenaikan menjadi sebesar Rp. 13.733.028.

Total aset pada tahun 2015 sebesar Rp.15..729.945, pada tahun 2016 total aset mengalami kenaikan menjadi sebesar Rp.16.745.695, dan pada tahun 2017 total aset mengalami kenaikan menjadi sebesar Rp.18.906.41.

makadapat dilihat hasil dari perhitungan total hutang dibagi total aset hasilnya dapat dilihat dari tabel diatas kesimpulannya adalah :

Menurut peneliti hasil perhitungan debt to assets ratiopada tahun 2015-2017 yang didapat perusahaan diatas standar industri perusahaan dikatakan kurang baik hal ini menyebabkan lebih dari separuh pendanaan dibiayai oleh utang karena total utang lebih banyak dibandingkan dengan aktiva. berdampak semakin sulit bagi perusahaan untuk memperoleh tambahan pinjaman, karena dikhawatirkan perusahaan tidak mampu menutupi utang-utangnya dengan aktiva yang dimilikinya

Menurut Kasmir (2018:151) Jika semakin tinggi debt to asset ratio yang didapat maka semakin buruk dan pendanaan dengan utang semakin banyak dan sebaliknya semakin kecil rasio debt to assets ratio maka semakin baik suatu dan semakin kecil perusahaan dibiayai oleh hutang. walaupun mengalami kenaikan hasil perhitungan rasionya tidak memperngaruhi keadaan karena baik tidak yang suatu perusahaan tergantung standar industri yang ditetapkan.

\section{b. Debt to Equity Ratio}

Debt to equity ratio adalah rasio yang digunakan untuk menilai utang dengan ekuitas. Rasio ini dicari dengan membandingkan antara seluruh utang, termasuk utang lancar dengan seluruh ekuitas.

TABEL 5

Perhitungan Debt to Equity Ratio

\begin{tabular}{|c|c|c|}
\hline Tahun & Debt to Equity ratio & $\begin{array}{c}\text { Standar } \\
\text { industri }\end{array}$ \\
\hline 2015 & $225 \%$ & \multirow{2}{*}{$90 \%$} \\
\hline 2016 & $255 \%$ & \multirow{2}{*}{. } \\
\hline 2017 & $265 \%$ & \\
\hline \multicolumn{2}{|c|}{ Sumber : data diolah oh penulis } \\
\end{tabular}

Sumber : data diolah oleh penulis 
Dari hasil penelitian dapat dilihat jika rata-rata standar industri debt to assets ratio adalah sebesar $35 \%$. Total utang pada tahun 2015 sebesar Rp. 10.902.585, pada tahun 2016 total utang mengalami kenaikan menjadi sebesar Rp. 12.041.437, dan pada tahun 2017 utang lancar mengalami kenaikan menjadi sebesar Rp.13.733.025.

Ekuitas pada tahun 2015 sebesar Rp.4.827.585, pada tahun 2016 ekuitas mengalami penenurunan menjadi sebesar Rp.4.704.258, dan pada tahun 2017 ekuitas mengalami kenaikan menjadi sebesar Rp.5.173.388.

makadapat dilihat hasil dari perhitungan total hutang dibagi ekuitas hasilnya dapat dilihat dari tabel diatas dan kesimpulannya adalah :

Menurut peneliti hasil perhitungan debt to equity ratio pada tahun 2015-2017 rasio yang diperoleh secara keseluruhan adalah tinggi dan diatas rata-rata industriPerusahaan dianggap kurang baik karenatotal debt to equity ratio menunjukkan kondisi keuanganyang sangat berbahaya bagi kreditur karena jumlah hutang lebih besar dari modal pemilik sehingga perusahaan tidak dapat memenuhi kebutuhan finansialnya.sebagian besar modalnya juga didanai oleh kreditur.

menurut Kasmir (2018.157) bagi bank semakin tinggi rasio ini akan semakin tidak menguntukan karena akan besar risiko yang ditanggung yang ditanggung atas kegagalan yang mungkin terjadi di perusahaan. Namun bagi perusahaan semakin besar rasio akan semakin baik. Sebaliknya rasio yang rendah, semakin tinggi tingkat pendanaan yang disediaakan pemilik dan semakin besar batas pengaman bagi pinjaman jika terjadi kerugian atau penyusutan aktiva tetap.Semakin besar rasio ini akan semakin tidak menguntungkan karena akan semakin besar resiko yang ditanggung atas kegagalan yang mungkin terjadi diperusahaan.

\section{KESIMPULAN DAN SARAN}

\section{1) Kesimpulan}

Berdasarkan dari hasil-hasil analisis rasio keuangan yang telah dilakukan terhadap tingkat likuiditas dan solvabilitas PT.Unilever Indonesia Tbk dapat disimpulkan sebagai berikut :

a) Berdasarkan rasio likuiditas daricurrent ratiopada tahun 2015-2017 masih berada dibawah rata-rata standar industri. hal ini menyebabkan perusahaan dalam keadaan tidak likuid dan perusahaan juga berada dalam kondisi yang kurang baik, karena aktiva lancar tidak bisa menjamin hutang lancar atau kewajiban-kewajiban perusahaan yang segera jatuh tempo. Sedangkan quick ratio pada tahun 2015-2017 masih berada dibawah rata-rata standar industri. hal ini menyebabkan perusahaan berada dalam kondisi yang kurang baik, disebabkan karena hutang lancar lebih besar dibandingkan dengan aset lancar yang dimiliki perusahaan dan juga karena rasio ini mengukur uji solvensi jangka pendek yang lebih detail karena tidak memasukan persediaan jika sudah tidak likuid jelas perusahaan akan mengalami kerugian.

b) Berdasarkan rasio solvabilitas dari debt to assets ratio pada tahun 2015-2017 yang didapat perusahaan diatas standar industri perusahaan dikatakankurang baik hal ini menyebabkan lebih dari separuh pendanaan dibiayai oleh utang karena total utang lebih banyak dibandingkan dengan aktiva. berdampak semakin sulit bagi perusahaan untuk memperoleh tambahan pinjaman. karena dikhawatirkan perusahaan tidak mampu menutupi utang-utangnya dengan aktiva yang dimilikinya.sedangkan debt to equity ratio pada tahun 2015-2017 rasio yang diperoleh secara keseluruhan adalah tinggi dan diatas rata-rata 
industri. Perusahaan dianggap kurang baik karenatotal debt to equity ratio menunjukkan kondisi keuanganyang sangat berbahayabagi kreditur karena jumlah hutang lebih besar dari modal pemilik sehingga perusahaan tidak dapat memenuhi kebutuhan finansialnya. Dan sebagian besar modalnya didanai oleh kreditur. Lebih besar utang dibandingkan aktiva.

c) Dampak dari rasio likuiditas dan solvabilitas terhadap pihak internal yaitu menganggu hubungan baik antara perusahaan dan pihak kreditur lainnya atau dengan para distributor. Kasus ini juga berdampak kepada para pelangan (konsumen). Hal ini menyebabkan perusahaan memperoleh krisis kepercayaan dari berbagai pihak yang selama ini membantu kelancaran usahanya. Dampak Terhadap pihak internal yaitu perusahaan akan sulit untuk memperoleh tambahan pinjaman dari kreditur dan akan hilang kepercaya anter hadap perusahaan tersebut.

\section{2) Saran}

Berdasarkan permasalahan yang ada pada PT.Unilever Indonesia Tbk mengenai penilaian kinerja keuangan perusahaan, maka penulis mencoba untuk memberikan saran bagi perusahaan antara lain :

a) Untuk rasio likuditas perusahaan, baik current ratio dan quick ratio sebaiknya perlu meningkatkan jumlah assets yang dimiliki agar kegiatan dalam membayar kewajiban dapat berjalan dengan baik, mengurangi hutang jangka pendek dan meningkatkan pendapatan atau laba usaha.

b) Untuk rasio solvabilitas, dikarenakan pada rasio ini mengukur sejauh mana asset perusahaan dibiayai oleh utang maka baik pada debt to assets ratio dan debt to equity ratio perusahaan sebaiknya mensiasati kelebihan dan kekurangan pada sumber dana yang dibutuhkan untuk meningkatkan asset dengan cara melakukan kombinasi dari masing-masing jumlah sumber dana atau dengan kata lain penggunaan dana yang bersumber dari pinjaman harus dibatasi agar tidak terlalu membebani perusahaan pada kewajibannya baik jangka pendek maupun jangka panjang.

c) Melihat perekonomian sekarang ini sebaiknya perusahaan lebih meningkatkan lagi ekuitas dan asset agar perusahaan tetap mendapat kepercayaan dari pihak kreditur. Dan perusahaan harus lebih memperhatikan lagi keadaaan perusahaan dan harus lebih teliti dalam menjalankan kegiatan operasional perusahaan terutama dalam penggunaan dana yang dimiliki.

\section{DAFTAR PUSTAKA}

Fahmi,Irham.2011. Analisis Laporan Keuangan. Cetakan Ke-2 Bandung : Alfabeta.

Harahap, Sofian Safri,2010. Analisis Kritis Atas Laporan Keuangan. Jakarta : Rajawali Pers.

Hery.2015. Analisis Laporan Kuangan Keuangan. Jakarta: PT.Bumi Aksara.

Sedarmayanti dan Hidayat Syarifudin. 2011. Metode Penelitian. Bandung : CV. Mandar Maju.

IAI.2018. Standar Akuntansi Keuangan.Jakarta :Ikatanan Akuntansi Indonesia. 
Jumingan. 2011. Analisis Laporan Keuangan. Jakarta : PT Bumi Aksara.

Jumingan. 2014. Analisis Laporan Keuangan. Jakarta : PT Bumi Aksara.

Kasmir.2015. Analisis Laporan Keuangan.Jakarta : Rajawali Pers.

Kasmir.2018. Analisis Laporan Keuangan. Edisi Satu. Cetakan Kesebelas. Depok : Rajawali Pers.

Munawir 2010.Analisis Laporan Keuangan.Cetakan Kelima Belas.Yogyakarta:

Liberty Yogyakarta.

Sugiyono. 2014. Metode Penelitian Bisnis.Bandung : CV. Alfabeta. 